\title{
HAMBATAN PENANAMAN NILAI-NILAI PANCASILA DALAM KEGIATAN ORGANISASI SISWA INTRA SEKOLAH (OSIS) DI SMPN 4 KLARI
}

\author{
${ }^{1}$ Yuli Fatimah \\ ${ }^{2}$ Aris Riswandi Sanusi \\ ${ }^{3}$ Yogi Nugraha \\ Universitas Buana Perjuangan Karawang \\ ${ }^{1}$ pk15.yulifatimah@mhs.ubpkarawang.ac.id \\ 2arissanusi@ubpkarawang.ac.id \\ 3yogi.nugraha@ubpkarawang.ac.id
}

\begin{abstract}
This study aims to determine the obstacles of intra school student organizations (OSIS) in planting pancasila values in junior high school 4 klari. The subject of this research is the supervisor of the intra school student organization, the intra and intra school student organization management students and the non intra school student organization management. The results of this study indicate that the obstacles in planting pancasila values through intra school students organization activities at SMPN 4 Klari karawang district are the obstacles that are often encountered in planting pancasila values in osis activities are still found students who are less active and not all students want to take part in student council activities, sometimes there is one student who spreads negative viruses and invites other friends not to participate in these activities, lack of individual awareness in carrying out congregational prayers, lack of maintaining facilities and cleanliness in the school environment.
\end{abstract}

\section{Keywords: Pancasila Values, Student Council}

\begin{abstract}
ABSTRAK
Penelitian ini bertujuan untuk mengetahui Hambatan Organisi Siswa Intra Sekolah (OSIS) dalam penanaman nilai Pancasila di SMP Negeri 4 Klari. Subjek penelitian ini adalah Pembina OSIS, peserta didik pengurus OSIS dan Peserta didik bukan pengurus OSIS. Hasil penelitian ini menunjukan bahwa hambatan dalam penanaman nilai nila Pancasila melalui kegiatan OSIS di SMP Negeri 4 Klari Kabupten Karawang yaitu, kendala-kendala yang sering dijumpai dalam penanaman nilai-nilai Pancasila dalam kegiatan OSIS adalah masih ditemukan peserta didik yang kurang aktif dan tidak semua peserta didik ingin mengikuti kegiatankegiatan OSIS, terkadang ada salah satu peserta didik yang menyebar virus negatif dan mengajak teman-teman yang lain untuk tidak mengikuti kegiatan-kegiatan tersebut, Kurangnya kesadaran individu dalam melaksanakan ibadah sholat berjamaah, kurangnya menjaganya fasilitas dan kebersihan yang ada di lingkungan sekolah.
\end{abstract}

\section{Kata Kunci : Nilai-Nilai Pancasila, OSIS}




\section{PENDAHULUAN}

Pendidikan akan semakin berkembang dengan adanya bantuan teknologi, karena semakin banyak referensi, membuat siswa aktif dengan mencari informasi lewat internet. Dan masih lebih banyak lagi dampak positif lainya yang dapat meningkatkan peningkatan mutu pendidikan. Selain memberikan dampak positif, globalisasi juga bisa saja memberikan dampak negatif bagi peserta didik, dampak negatif yang dapat dirasakan diantaranya adalah, kualitas moral peserta didik yang semakin menurun karena di internet siapapun dapat mengakses informasi tanpa batas, sehingga tidak menutup kemungkinan peserta didik membuka informasi yang kurang baik sehingga berpengaruh pada tingkah laku dan pola fikir peserta didik, Menipisnya kebudayaan lokal karena masuknya budaya dari luar.

Dampak negatif yang muncul dari globalisasi pendidikan, masyarakat selalu mencari upaya-upaya untuk mengurangi atau mencegah adanya dampak negatif. Penulis berfikir bahwa upaya dan solusi yang dapat dilakukan dari permasalahan tersebut adalah upaya dalam kearifan lokal bagi para peserta didik adalah bersekolah, di zaman yang sudah modern sekarang setiap orang tua pasti ingin anak-anaknya bisa bersekolah setinggi-tingginya sesuai dengan cita-cita yang ingin dicapai. Mengapa bersekolah ? karena dengan bersekolah akan adanya interaksi antara guru dan peserta didik, selain itu peserta didik bisa bertatap muka langsung dengan guru yang mengajar dibandingkan dengan hanya mencari informasi atau belajar dari vidio, selain itu bersosialisasi juga dapat dirasakan oleh peserta didik di sekolah terutama di kelas. Sehingga siswa dapat mengerti bahwa tidak semua hal itu bersifat praktis. Tidak melupakan budaya lokal dan mengurangi kesenjangan sosial dengan teknologi tetapi tetap bersosialisasi agar dapat mengerti tentang masyarakat dan lingkungan sekitar. Selain itu upaya gotong royong perlu diterapkan karena adengan adanya kegiatan gotong royong yang di terapkan akan memberikan nilai-nilai sosial dalam kehidupan dan meningkatkan kinerja kerjasama. Menjauhkan peserta didik dari internet atau gadget bisa meningkatkan sosialisasi karena dengan menjauhkan dari internet atau gadget akan ada terjadinya interaksi antara satu orang dengan yang lainya, dalam hal ini akan mengurangi terjadinya kesenjangan sosial. Saat belajar bersama bila satu orang tidak memegang handphone maka orang yang lainya juga tidak akan memegang handphone, menurut Hassan (2003:161) Mengemukakan bahwa : "Setiap bangsa atau Negara tentu mempunyai suatu cara tersendiri untuk menagkis pengaruh pengaruh dari luar yang dapat berdampak negatif terhadap bangsanya. Demkian juga bagi Indonesia punya falsafah hidup yang adiluhung. Gotong royong, kekeluargaan dan tepo sliro, eling Ian waspodho, andhap asor dan halus budi pekertinya. Kata-kata seperti itu sekarang sudah tidak dimaknai dengan benar dan sudah luntur bersama dekadensi moral seiring dengan tawaran globalisasi yang makin melaju kencang”.

Upaya-upaya ini dapat diterapkan dalam kehidupan sehari-hari oleh peserta didik agar dapat mengurangi pengaruh dampak negatif dari globalisasi yang terjadi saat ini. Globalisasi memiliki dampak negatif dan positif, tetapi bagi peserta didik yang berpendidikan tentunya kita harus mampu untuk memanfaatkan teknologi dengan baik dan mampu meminimalisir dampak negatif dari globalisasi.

Krisis moral yang dialami bangsa Indonesia sudah sangat memprihatinkan dan berdampak serius di kalangan remaja dan bukan merupakan permasalahan sederhana. Perilaku-perilaku tersebut sudah mengarah pada tindakan yang bertentangan dengan nilai Pancasila yang melanda Indonesia seperti contohnya tawuran 
sampai kriminalitas. Fenomena tersebut banyak terjadi di kalangan pelajar dan generasi muda Indonesia. generasi muda yang merupakan calon tulang punggung dan penerus bangsa malah melakukan hal yang bertentangan dengan Pancasila. Generasi muda akan kehilangan fungsinya sebagai penerus bangsa jika hal negatif tersebut terus berlangsung dan tidak di cegah. Lunturnya nilai-nilai Pancasila sebagai pedoman hidup berdampak pada tingkah laku yang tidak mengindahkan ketuhanan, kemanusiaan, persatuan, kerakyatan dan keadilan. Dengan adanya kasus tersebut jika diteruskan pasti akan menjadikan bangsa Indonesia semakin mengalami keterpurukan, sehingga penanaman nilai-nilai Pancasila di lingkungan sekolah itu sangatlah penting karena penanaman nilai-nilai Pancasila sangat erat kaitanya dengan pendidikan karakter peserta didik. Hal tersebut akan membentuk pribadi peserta didik, agar kelak menjadi manusia dan warga negara Indonesia yang baik.

Tujuan nasional bangsa Indonesia seperti yang ada di dalam UUD 1945 adalah untuk melindungi segenap bangsa Indonesia dan seluruh tumpah darah Indonesia dan memajukan kesejahteraan umum, mencerdaskan kehidupan bangsa dan ikut melaksanakan ketertiban dunia yang berdasarkan kemerdekaan perdamaian abadi dan keadilan sosial. Untuk tercapainya tujuan pembangunan nasional tersebut di butuhkan antara lain tersedianya sumber daya manusia yang tangguh, mandiri serta berkualitas. menurut Gesmi (2018:5) Mengatakan bahwa "Pancasila yang dibuat sebagai dasar negara juga dibuat untuk menjadi tujuan negara dan cita-cita bangsa. Kita sebagai bangsa Indonesia haruslah mengidamkan sebuah negara yang punya Tuhan yang esa punya kemanusiaan yang tinggi, bersatu serta solid, selalu bermusyawarah dan juga munculnya keadilan sosial”.
Terlihat dari rumusan sila-sila Pancasila itu sendiri memperlihatkan adanya sifat umum yang menyeluruh dan terwujud, maka dari itu di dalam kehidupan bermasyarakat Pancasila merupakan nilainilai pokok, nilai-nilai tersebut dapat diterapkan untuk generasi muda demi tercapainya cita-cita bangsa menjadikan bangsa Indonesia melahirkan generasigenerasi muda yang berkualitas dan terdidik. menurut Setijo (2002:10) Mengemukakan bahwa: "Tentang hakikat nilai sila-sila Pancasila perlu di tengarai makna dan arti dari setiap sila Pancasila secara hakiki agar kita mendapatkan gambaran tentang inti arti Pancasila yang semuanya akan sangat berkaitan dengan hal ikhwal dalam uraian selanjutnya.

Maka, sudah tepat hanya lima sila itu yang dimasukan dalam dasar filsafat negara sebagai inti kesamaan dari segala keadaan yang beraneka warna itu dan juga telah mencukupi, dalam arti tidak ada lainya yang tidak dapat dikembalikan kepada salah satu sila dari Pancasila". Pancasila sebagai ideologi bangsa yang dijadikan pedoman warga negara merupakan wadah yang sangat penting untuk merubah etika dan moral calon penerus bangsa, karena sangat disayangkan jika pelajar yang seharusnya menjadi penerus bangsa untuk memajukan negara Indonesia ke arah yang lebih baik malah melakukan hal negatif di luar dari sikap apa yang seharusnya dimiliki oleh seorang yang terdidik. Dengan demikian perlunya inovasi baru untuk mengembangkan nilainilai Pancasila pada calon penerus bangsa, peserta didik contohnya. menurut Rosma (2017:173) mengatakan bahwa "Dengan demikian sangat penting dan mendesak untuk melakukan kajian terhadap upaya pengenalan dan pengamalan nilai-nilai Pancasila yang dilakukan oleh masingmasing lembaga pendidikan, baik kajian teorinya, maupun pelaksanaanya, bahkan keterlibatan masyarakat dalam pembinaan harus dijadikan bagian penting dalam 
upaya mengenalkan dan pengamalan nilainilai Pancasila kepada generasi muda".

Organisasi secara umum merupakan sebuah perkumpulan/hubungan yang sistematis dan efektif untuk mencapai suatu tujuan dan diharapkan mencapai hasil yang diinginkan bersama, organisasi di sekolah mempunyai unsur penting yaitu mencakup pembagian kerja pada peserta didik, masing-masing para peserta didik mempunyai tugas dan tanggungjawabnya yang berbeda demi untuk mencapai tujuan bersama. Mereka juga diberikan kekuasaan untuk menjalankan tugas-tugas mereka secara efektif. Menurut Darmono (2007:34) Mengatakan bahwa : "Organisasi adalah setiap bentuk persekutuan antara dua orang atau lebih yang bekerja sama untuk mencapai suatu tujuan bersama dan terikat secara formal dalam suatu ikatan hirarkis dan selalu terdapat hubungan antara seorang atau sekelompok orang yang disebut pimpinan dan seorang atau sekelompok orang yang disebut bawahan. Butir-butir penting yang dapat dirumuskan dari definisi organisasi adalah : Adanya kelompok orang yang bekerjasama, Adanya tujuan tertentu yang akan dicapai, Adanya pekerjaan yang akan dikerjakan, Adanya penetapan dan pengelompokan pekerjaan, Adanya wewenang dan tanggungjawab, Adanya pedelegasian wewenang, Adanya hubungan satu sama lain, Adanya penempatan orang yang akan melakukan pekerjaan, Adanya tata tertib yang harus ditaati. Dari serangkaian butirbutir yang ada di dalam wadah organisasi dapat dirumuskan bahwa organisasi mempunyai tujuan yang jelas dan memiliki kesatuan arah dalam kelompok organisasi, adanya keseimbangan antara tugas dan tanggungjawab serta adanya pembagian tugas.

Pendapat tersebut di atas menyatakan bahwa nilai-nilai Pancasila memang harus diterapkan melalui kegiatan-kegiatan yang mampu membangkitkan nilai-nilai
Pancasila. Ini karena siswa yang sudah lupa akan nilai-nilai Pancasila akibat globalisasi. Masuknya kebudayaan asing dapat melunturkan nilai-nilai Pancasila dan kebudayaan bangsa. Karna daya tarik kebudayaan luar sungguh lah luar biasa.

Berdasarkan pemaparan di atas, karena rendahnya penanaman nilai-nilai Pancasila pada peserta didik, maka peneliti tertarik untuk menganalisa lebih jauh mengenai hal tersebut. Dengan demikian maka peneliti tertarik untuk melakukan penelitian yang berjudul "Hambatan Penanaman NilaiNilai Pancasila dalam Kegiatan Organisasi Siswa Intra Sekolah (OSIS) Di SMPN 4 Klari”

\section{METODE}

Pendekatan yang digunakan dalam penelitian ini adalah pendekatan kualitatif dengan metode deskriptif, penelitian kualitatif yaitu pendekatan penelitian yang diawali teori menuju data dan berakhir pada penerimaan atau penolakan terhadap teori yang digunakan. Penelitian kualitatif dilakukan dengan metode wawancara dan observasi. Subjek penelitian adalah subjek yang dituju untuk diteliti oleh peneliti. Maka subjek penelitian yang akan diteliti adalah siswa VIII SMPN 4 Klari dan yang menjadi objek penelitian peneliti yaitu mengenai penanaman nilai, yang tidak lain penelitian ini ialah tentang" Penanaman Nilai-nilai Pancasila dalam Kegiatan Organisasi Siswa Intra Sekolah”.

Teknik pengumpulan data dilakukan melalui wawancara, observasi, studi dokumentasi. Pada penelitian kali ini peneliti memilih jenis penelitian kualitatif maka data yang diperoleh haruslah mendalam, jelas dan spesifik. Teknik analisis data dalam penelitian ini diantaranya yaitu reduksi data, display data, penarikan kesimpulan. 


\section{HASIL DAN PEMBAHASAN}

Berdasarkan hasil penelitian, dalam penanaman nilai nilai Pancasila dalam kegiatan OSIS pasti menemukan suatu masalah yang akan menghambat proses terjalanya suatu kegiatan dan harus dicari solusinya agar kegiatan bisa berjalan dengan baik. Penentuan di izinkan atau tidaknya kegiatan disekolah berlangsung itu semua tak lepas dari kebijakan sekolah dalam memberikan izin kepada OSIS untuk melangsungkan kegiatan tersebut, setiap organisasi yang ingin mengadakan kegiatan disekolah harus mengikuti prosedur perizinan dan membuat proposal kegiatan. Kemudian proposal tersebut diserahkan terlebih dahulu kepada pembina OSIS. Setelah mendapat persetujuan pembina OSIS kemudian di presentasikan ke bagian kesiswaan, selanjutnya kegiatan boleh dilaksanakan jika sudah mendapat persetujuan dari berbagai pihak. Masih banyak berbagai kendala dan hambatan yang ada dalam lingkup OSIS, salah satunya adalah Sebagai seorang pelajar para pengurus OSIS akan disibukan dengan tugasnya masing masing terutama dalam tanggungjawab seorang pelajar terkadang kurangnya perhatian peserta didik dengan kewajibanya dalam hal berpartisipasi atau musyawarah terhadap program kegiatan OSIS.

Penanaman nilai nilai Pancasila tidaklah mudah dipraktekkan dalam keseharian maupun dalam kegiatan yang diadakan OSIS, bahkan nilai nilai Pancasila kini semakin menjauh dan bisa dikatakan sudah memudar. Adapun kendala-kendala yang sering dijumpai dalam penanaman nilai-nilai Pancasila dalam kegiatan OSIS adalah masih ditemukan peserta didik yang kurang aktif dan tidak semua peserta didik ingin mengikuti kegiatan-kegiatan OSIS. Tidak mudah untuk mengajak peserta didik ketika ada kegiatan-kegiatan yang diadakan di sekolah, terkadang ada salah satu peserta didik yang menyebar virus negatif dan mengajak teman-teman yang lain untuk tidak mengikuti kegiatan-kegiatan tersebut. Kesadaran beragama peserta didik juga masih belum matang dan ada pada tahap meniru, di mana para peserta didik hanya menunggu dan mengikut-ikuti temanya saja dalam menjalankan kegiatan religius bukan dorongan dari hati sendiri. Contohnya ketika diadakanya kegiatan acara memperingati Maulid Nabi yang bertujuan untuk menanamkan nilai nilai religius pada peserta didik, ada saja sebagian peserta didik yang mempengaruhi peserta didik yang lain mengajak ke kantin atau bolos saja dan menghindari kegiatan yang sedang berlangsung.

Selain itu ada juga ketika sudah memasuki waktu shalat dzuhur berjama'ah ada sebagian peserta didik yang hanya mengikuti temanya saja dan takut kepada guru jika tidak mengikuti shalat dzuhur berjama'ah mereka takut dimarahi, bukan dari keinginan sendiri dan tergerak hatinya untuk menjalankan shalat dzuhur berjama'ah. Di sekolah SMP Negeri 4 Klari masih terdapat perbuatan yang kurang baik seperti penanaman rasa cinta kebersihan ditunjukan pada dua hal yaitu menjaga kebersihan diri sendiri dan kebersihan lingkungan. Karena kedua itu sangat berpengaruh dan akan menjadi hambatan ketika diadakanya kegiatan OSIS. Kebersihan terhadap diri sendiri dimaksud agar membentuk pribadi yang sehat dan kuat sehingga tidak mengganggu aktivitas yang ada di sekolah, karena jika tidak bisa menjaga diri dari kebersihan bahkan sampai sakit semua itu akan jadi penghambat terjalanya suatu program kegiatan OSIS.

Masih ditemukan salah satu peserta didik yang tidak bisa menjaga dan merawat fasilitas yang ada di sekolah seperti contohnya toilet, sekolah sudah menyediakan toilet 1 kelas 1 meskipun belum semua dibuatkan akan tetapi itu sudah meringankan peserta didik supaya tidak terlalu jauh ketika ke toilet, namun peserta didik tidak merawatnya bahkan 
malah dirusak temboknya di corat coret dan pintu toilet cepat rusak, bahkan sampai ada yang jika sesudah menggunakan toilet tidak dibersihkan dan itu bisa mengundang penyakit. Para peserta didik belum sepenuhnya mematuhi dan melaksanakan aturan tata tertib sekolah, adanya peraturan yang diberlakukan oleh pihak sekolah memiliki peran yang sangat penting dalam menanamkan kedisiplinan peserta didik yang bertujuan untuk pencapaian tahap di mana peserta didik yang tadinya mematuhi peraturan yang ditetapkan di sekolah karena rasa takut menjadi sadar akan peraturan yang berlaku.

Dengan ketidak teraturan bisa menyebabkan semua kegiatan yang diadakan OSIS di sekolah menjadi tidak efektif, para peserta didik masih ada yang datang terlambat ketika kegiatan berlangsung dan akhirnya kegiatanpun terganggu. Demi tercapainya sebuah kegiatan tentu harus memiliki Rencana Anggaran Dana agar proses kegiatan OSIS bisa berjalan dengan baik, karena untuk menjalankan sebuah kegiatan membutuhkan dana yang tidak sedikit dan jika sampai terjadi keterlambtan dana OSIS dengan minimnya anggaran OSIS yang ada akan menjadi sebuah hambatan untuk terjalanya suatu proses program kegiatan OSIS.

Pendidikan merupakan faktor penting yang sangat menentukan kehidupan manusia untuk meningkatkan kualitas sumber daya manusia. Keberhasilan sebuah pendidikan tidak hanya diukur melalui materi dan kecanggihan teknologi yang digunakan, akan tetapi juga ditentukan oleh keluhuran karakter dan budi pekerti yang luhur. Hal ini dikarenakan dalam dunia pendidikan tidak hanya semata-mata ditentukan oleh kecerdasan intelektual saja akan tetapi diperlukan juga kecerdasan emosi dan sosial. Gejala-gejala kemerosotan karakter dan moral pada remaja yang sangat mengganggu dan harus di waspadai. Menurut Lickona, 2013: 18 mengatakan bahwa tanda-tanda kemerosotan yang dimaksud adalah sebagai berikut: "Kekerasan dan vandalisme, yaitu meningkatnya kekerasan di kalangan remaja, Mencuri, yaitu mengambil barang milik orang lain yang dilakukan oleh remaja, Curang, yaitu budaya ketidakjujuran.Tidak menghormati figur otoritas, yaitu semakin rendahnya rasa hormat kepada orang tua dan guru, Kekejaman teman sebaya, yaitu pengaruh peer-group yang kuat dalam tindak kekerasan, Kefanatikan, yaitu menimbulkan rasa curiga dan kebencian diantara sesame, Bahasa yang kasar, yaitu menggunakan bahasa yang kasar dan katakata yang buruk, Pelecehan dan perkembangan seksual yang terlalu cepat, Meningkatnya sifat mementingkan diri sendiri dan menurunnya tanggung jawab sebagai warga Negara, Perilaku merusak diri, seperti penggunaan narkoba, alkohol dan seks bebas". Dalam menjadi pengurus OSIS selalu saja ada hambatan dan masalah yang dialami ketika pelaksanaan kegiatan OSIS terutama dalam penanaman nilai nilai Pancasila pasti menemukan suatu masalah yang akan menghambat proses terjalanya suatu kegiatan dan harus dicari solusinya agar kegiatan bisa berjalan dengan baik. Pembina OSIS membimbing pengurus OSIS melakukan penanaman nilai-nilai Pancasila mealalui berbagai macam kegiatan di sekolah. Hambatan dalam kegiatan OSIS sering terjadi baik dari proses penanaman nilai-nilai Pancasila maupun mengadakan sebuah kegiatan di sekolah. Semua itu merupakan sebuah tantangan bagi anggota OSIS maupun pembina OSIS sekalipun. Dalam sebuah Organisasi pasti akan adanya hambatan, jadikan hambatan tersebut merupakan sebuah tantangan sekaligus membuat OSIS bisa lebih berkembang lagi. Hambatan penanaman nilai-nilai Pancasila dalam kegiatan OSIS ada pada anggota OSIS dan para peserta didik di sekolah, karena dalam implementasi nilai-nilai Pancasila dalam 
sebuah kegiatan tidak selalu berjalan dengan mulus dan sesuai dengan apa yang diharapkan, pasti banyak sekali hambatanhambatan yang terjadi.

Menurut E. Mulyasa, 2011: 265, Mengatakan bahwa "Pelaksanaan pendidikan karakter berpusat pada satuan pendidikan secara holistik. Satuan pendidikan merupakan sektor utama yang yang paling optimal memanfaatkan dan memberdayakan semua lingkungan belajar yang ada untuk menginisiasi, memperbaiki, menguatkan dan menyempurnakan secara terus-menerus proses pendidikan karakter di satuan pendidikan. Pengambangan karakter dibagi dalam empat pilar, yakni kegiatan belajar mengajar di kelas, keinginan keseharian dalam bentuk pengembangan budaya satuan pendidikan, kegaiatan ko-kurikuler dan/atau ekstrakurikuler, serta kegiatan keseharian di rumah dan masyarakat".

Budaya budaya seperti ini adalah suatu hambatan bagi sebuah Organisasi karna akan menjadi sebuah penghambat proses kegiatan OSIS. Selain itu terkadang anggota OSIS ataupun pembina OSIS masih menemukan peserta didik yang kurang aktif. Dalam sebuah organisasi pasti akan adanya kendala-kendala yang ditemui bahkan bisa dikatakan menjadi sebuah hambatan dan menjadi tantangan bagi OSIS untuk bisa menanggulangi hal-hal negatif dan disa mengarahkan ke hal-hal yang positif seperti mengikuti tata tertib dan peraturan sekolah yeng telah dibuat. Selain itu hambatan lainya seperti munculnya pelanggaran OSIS, Tata tertib OSIS dibuat berdasarkan nilai nilai yang dianut di sekolah seperti nilai ketaqwaan, sopan santun, pergaulan, kedisiplinan, dan ketertiban, kebersihan, kesehatan, kerapihan, keamanan dan nilai nilai yang lain yang mendukung proses kegiatan belajar serta pengamalan dalam penanaman nilai di sekolah. Demi tercapainya suatu proses program kegiatan yang diadakan disekolah tentu harus adanya Rencana
Anggaran Dana, karena untuk menjalankan sebuah kegiatan itu memerlukan dana yang tidak sedikit. Jika terjadi keterlambatan Anggaran Dana itu dapat menjadi penghambat dalam perencanaan program kegiatan OSIS.

Berbagai macam hambatan yang ditemukan di sekolah baik itu dari anggota OSIS maupun hambatan dari seluruh para peserta didik di SMP Negeri 4 Klari, karena untuk menjadi pengurus OSIS ada istilah untung dan ruginya menjadi salah satu bagian dari organisasi sekolah bahkan bisa dikatakan ada keuntungan dari segi positif dan kerugian dari segi negatif. Dari segi positif yang dirasakan oleh sebagian anggota OSIS adalah adanya kepuasan dan kesenangan diri ketika menjadi bagian dari OSIS yang tidak bisa diukur dengan materi, Karena dengan menjadi bagian dari OSIS itu adalah salah satu orang orang pilihan yang diberikan kepercayaan yang lebih dari pihak sekolah dan teman temanya untuk berbuat hal yang positif yang bisa mengharumkan nama baik sekolah. Jika semua itu dijalankan dengan sebaik mungkin dan tercapainya suatu tujuan untuk mengharumkan nama baik sekolah disitulah adanya kepuasan sendiri dan kebanggaan sendiri menjadi bagian dari OSIS yang dapat membawa nama baik sekolah. Namanya Pasti di kenang oleh guru guru dan teman teman di sekolah sebagai peserta didik yang aktif dalam berorganisasi dan berprestasi tentunya.

Namun ternyata ada sisi negatifnya juga ketika berada dalam bagian organisasi sekolah seperti ketidakmampuan membagi waktu antara pelajaran dan organisasi, sesungguhnya itu menjadi sebuah hambatan bagi kepengurusan OSIS karena mereka harus rela tertinggal mata pelajaran serta nilai nilai pengurus OSIS menjadi turun. Selain dari pihak sekolah dari orang tua para pengurus OSIS terkadang mengeluh merasa anaknya jarang ada dirumah dan selalu disibukan dengan kegiatan kegiatan sekolah bahkan jika 
sudah waktunya pulang pengurus OSIS sering terlambat sampai di rumah karena terkadang ada rapat mendadak sepulang sekolah.

Belum lagi ada sebagian guru yang
merasa kurang senang dengan kepengurusan OSIS karena seringkali meminta izin keluar kelas sehingga tidak bisa mengikuti pelajaran dengan alasan harus mengikuti rapat OSIS atau sedang berlangsungnya kegiatan OSIS. Semua itu harus segera di atasi dan sedikit demi sedikit adanya perbaikan agar OSIS di SMP Negeri 4 Klari menjadi OSIS yang aktif dan kegiatan kegiatan yang dijalankan oleh OSIS bisa terealisasikan mewujudkan visi dan misi sekolah serta dapat mencapai tujuan membawa nama baik sekolah.

\section{SIMPULAN}

Dari hasil penelitian yang di dapat, di SMP Negeri 4 Klari sudah menjalankan berbagai macam kegiatan yang diadakan di sekolah. Namun adanya Hambatan dalam proses penanaman nilai nilai Pancasila dalam kegiatan OSIS adalah penanaman nilai nilai Pancasila tidaklah mudah di praktekan dalam keseharian maupun dalam kegiatan yang diadakan OSIS. Masih banyak hambatan yang ditemukan dalam penanaman nilai Pancasila dalam kegiatan OSIS seperti masih ditemukan peserta didik yang kurang aktif dan tidak semua peserta didik ingin mengikuti kegiatan kegiatan OSIS, kendala-kendala yang sering dijumpai dalam penanaman nilainilai Pancasila dalam kegiatan OSIS adalah masih ditemukan peserta didik yang kurang aktif dan tidak semua peserta didik ingin mengikuti kegiatan-kegiatan OSIS, terkadang ada salah satu peserta didik yang menyebar virus negatif dan mengajak teman-teman yang lain untuk tidak mengikuti kegiatan-kegiatan tersebut, Kurangnya kesadaran individu dalam melaksanakan ibadah sholat berjamaah, kurangnya menjaganya fasilitas dan kebersihan yang ada di lingkungan sekolah.

\section{DAFTAR PUSTAKA}

Darmono (2007).Perpustakaan Sekolah. Jakarta : Grasindo

E. Muyasa, 2011, Manajemen Berbasis Sekolah Konsep Strategi dan Implementasi, Bandung : PT Remaja Rosdakarya

Gesmi (2018). Pendidikan Pancasila. Ponorogo : Uwais Inspirasi Indonesia.

Hassan. (2003). Konfigurasi Identitas Nasional, Nasionalisme dalam Era Globalisasi Suat Harapan dan Tantangan. Hal 161

Lickona, Thomas, 2013, Pendidikan Karakter, Panduan Lengkap Mendidik Siswa Menjadi Pintar dan Baik, Bandung, Penerbit Nusa Media

Rosma.(2017). Integrasi nilai-nilai Pancasila Melalui Kegiatan Keagamaan dalam Program Jam ke Nol. Palembang : Management. Vol 2.Hal 173-174.

Setijo (2002). Pendidikan Pancasila. Jakarta : Grasindo

Sugiyono. (2017). Metodologi Penelitian. Bandung: Alfabeta 